\title{
O języku kina inaczej
}

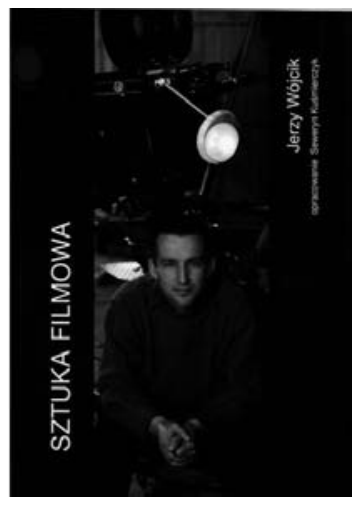

\section{ROBERT BIRKHOLC}

Zmarły w kwietniu 2019 r. Jerzy Wójcik zapisał się w historii Dziesiątej Muzy nie tylko jako wybitny operator filmowy i pedagog wykładający na kilku polskich uczelniach, ale też jako filozof kina. Właśnie harmonijne połączenie tych trzech ról zadecydowało o wyjątkowości Sztuki filmowej, książki złożonej z wykładów, które artysta wygłosił dla studentów Wydziału Polonistyki Uniwersytetu Warszawskiego w latach 2000-2003. Wystąpienia miały charakter rozbudowanych prelekcji, po których następowały pokazy arcydzieł światowego kina - od Człowieka z Aran (1934) Roberta Flaherty'ego po Chungking Express (1994) Wonga Kar-waia. Wykłady zostały zarejestrowane na użytek własny przez Seweryna Kuśmierczyka, a po latach przez niego spisane i opracowane. Sztuka filmowa, będąca dopełnieniem wydanego przed laty Labiryntu światła Wójcika ${ }^{1}$, to swego rodzaju suma przemyśleń operatora o kinie jako medium opowiadania o doświadczeniu wewnętrznym.

W czasie kiedy na rynku ukazuje się coraz więcej praktycznych poradników na temat produkcji filmów, publikacja Wójcika wydaje się pozycją niemalże egzotyczną, a zarazem bardzo potrzebną. Jak sugeruje sam tytuł, Sztuka filmowa nie jest bowiem kolejnym podręcznikiem zdradzającym sekrety „kuchni filmowej” ta gastronomiczna metafora z pewnością nie przypadłaby zresztą do gustu samemu autorowi, który zajmował się przede wszystkim artystycznym wymiarem kina. Nie mamy tu również do czynienia ze stricte naukowym, teoretycznym wywodem systematyzującym wiedzę o filmie. Jeżeli chodzi o formę wypowiedzi, publikacja przypomina raczej klasyczne traktaty o sztuce niż współczesne publikacje filmoznawcze. Wójcik posługuje się stylem eseistycznym, a nie typowym dyskursem akademickim i odwołuje się do rozmaitych dziedzin nauki, ale też do własnych doświadczeń, zarówno zawodowych, jak i osobistych.

Wykłady zamieszczone w Sztuce filmowej zostały poświęcone poetyce kina oraz poszczególnym elementom języka filmowego: kompozycji obrazu, światłu, czasowi, rytmowi, montażowi czy dźwiękowi. Nie przypadkiem pierwszy rozdział nosi jednak tytuł Sens, a zatem dotyczy zagadnienia należącego - przynajmniej teoretycznie - do zupełnie innego porządku. W perspektywie Wójcika najistotniejsza jest bowiem naczelna zasada spajająca elementy filmowe w całość i wyznaczająca im określone funkcje. Dzieło sztuki składa się z poszczególnych części, ale muszą one „mieć świadomość” całości - uważa artysta, inspirując się między innymi rozpoznaniami Juliusza Żórawskiego, autora niedocenionej pracy O budowie formy architektonicznej ${ }^{2}$. Skrupulatne badanie kompozycji filmowej i koncentracja na wzajemnych odniesieniach elementów strukturalnych zbliżają myśl polskiego operatora do ujęć formalistycznych i strukturalistycznych, jednak ana- 


\section{O JĘZYKU KINA INACZEJ}

logia ta okazuje się zwodnicza. „Sens” dla Wójcika nie jest bowiem jedynie pewnym znaczeniem zamkniętym w dziele. Najważniejsze jest to, co wykracza poza immanencję tekstu - epifania związana z odbiorem utworu filmowego, rozszerzenie życia wewnętrznego odbiorcy.

Trzeba podkreślić, że ustalenia teoretyczne Wójcika tworzą spójną całość z jego dokonaniami artystycznymi. Zdjęcia wykonywane przez operatora nigdy nie były jedynie ozdobnikiem estetycznym, zawsze zawierały sens opowieści i oddawały stan wewnętrzny bohaterów. Wyrażając idee za pomocą światła, Wójcik pozostawał de facto współautorem filmów, przy których pracował. Rozterki Maćka Chełmickiego w Popiele i diamencie (1958) Andrzeja Wajdy są oddane między innymi za pomocą subtelnej kompozycji kadru, a finałowy obraz przedstawiający konającego bohatera w pozycji embrionalnej - a więc zwiastującej odrodzenie - można potraktować jako klucz do interpretacji całej opowieści ${ }^{3}$. Świat wewnętrzny ludzi naznaczonych wojną zyskuje w Nikt nie woła (1960) Kazimierza Kutza reprezentację przede wszystkim w sposobie przedstawienia relacji między postaciami a przestrzenią. Światło użyte w Faraonie (1966) Jerzego Kawalerowicza odsyła do sfery sacrum, tworząc symboliczne ramy historii młodego władcy ${ }^{4}$. Podczas swojej drogi twórczej Wójcik nie tylko eksplorował operatorskie środki wyrazu, ale też próbował przeniknąć samą istotę światła. Owocem tych przemyśleń jest właśnie Sztuka filmowa.

Przekazywana w Sztuce filmowej fachowa wiedza zawsze jest obudowywana refleksją estetyczno-filozoficzną. Wójcik nie zadowala się technicznymi, pragmatycznymi definicjami elementów języka filmowego. Przykładowo montaż nie jest dla autora jedynie sposobem łączenia ujęć, ale organizacją świata, procesem, który zostaje sfinalizowany na etapie postprodukcji, ale realizuje się od początku powstawania filmu. Wójcik odrzuca też klasyczną definicję ujęcia jako odcinka zawartego między dwoma cięciami montażowymi. Ujęcie zaczyna się - uważa autor - nie wtedy, kiedy włączamy kamerę, ale gdy następuje synchronizacja aktora, pracy kamery i przestrzeni. Jak bowiem stwierdza artysta, tak naprawdę we wspótczesnej kinematografii nie chodzi o kadry czy plany, ale o umiejętność opowiadania o bycie człowieka na ziemi (s. 38). Wójcik, niechętny wobec przeciętnej produkcji filmowej, próbuje opisać język nie kina, ale „sztuki filmowej”, która jego zdaniem zawsze powinna przekazywać głęboki sens, a jednocześnie być wewnętrznie spoista i zintegrowana.

Oczywiście kategoryczny podział na sztukę i niesztukę filmową jest tyleż subiektywny, ile dyskusyjny. Gwoli ścisłości trzeba jednak dodać, że autor nie tworzy poetyki normatywnej, lecz wskazuje różnorodność technik, stylów oraz poetyk mogących tworzyć wybitne kino. Użycie długich obiektywów, które pozwalają kierować stopniem ostrości, może stymulować wyobraźnię odbiorcy, co nie znaczy, że są one lepszym narzędziem artystycznym niż obiektywy krótkie; o świecie wewnętrznym człowieka można opowiadać równie wnikliwie za pomocą narracji behawiorystycznej, jak przez technikę introspekcji; znakomitym środkiem wyrazu może być zarówno układ otwarty kadru, metonimicznie odsyłający do przestrzeni pozakadrowej, jak i kompozycja zamknięta (występująca np. w filmach Petera Greenawaya) itd. Artysta nie faworyzuje jednego modelu kina, lecz odwołuje się do twórców tak różnych, jak Orson Welles i Ingmar Bergman, Federico Fellini i Robert Bresson, Akira Kurosawa i Rainer Werner Fassbinder.

W odróżnieniu od autorów „gramatyk filmowych” Wójcik nie poprzestaje na opisie znaczeniotwórczych funkcji technik audiowizualnych, lecz osadza refleksję 
o kinie w znacznie szerszym, historyczno-kulturowym dyskursie o wizualności. Szczególnie interesująca jest konfrontacja wschodnio- i zachodniochrześcijańskiego modelu przedstawienia, która pozwala uchwycić istotę dzieł takich twórców, jak Andriej Tarkowski i Siergiej Paradżanow. Konstrukcja obrazu w filmach zachodnich reżyserów kontynuuje według autora tradycję, która narodziła się w renesansie, a jest oparta na perspektywie linearnej oraz dialektyce światła i cienia, wyrażającej jasność i ciemność naszej egzystencji, śmierć i odrodzenie. Jednak w zupełnie inny sposób są skomponowane chociażby Barwy granatu Paradżanowa, gdzie nie występują światłocienie, a przestrzeń jest pozbawiona perspektywy zbieżnej. Wójcik łączy ten modus przedstawienia z założeniami wschodniego chrześcijaństwa, zgodnie z którym obiekty nie tyle są oświetlane, ile konstruowane przez światło. My jesteśmy świattem, dlatego nie możemy być oświetlani. Jesteśmy niejako konstrukcja, która jest jedynie znakiem ikonicznym tego, co nadprzyrodzone (s. 69) - referuje autor myśl wschodniochrześcijańską. Kontekst ten pozwala zinterpretować Barwy granatu jako pean na cześć kultury - zarazem materialnej i duchowej, zanurzonej w czasie i wiecznej. Za pomocą skomplikowanych zabiegów filmowych Paradżanow i Tarkowski ${ }^{5}$ próbują przełożyć zasady ikon na język kina i proponują model dzieła sztuki filmowej nieznany w postrenesansowej tradycji zachodniej.

Tradycja ikonograficzna, zgodnie z którą obraz powinien otwierać patrzącego na świat duchowy, wydaje się zresztą bardzo bliska Wójcikowi. Autor zdjęć do Matki Joanny od Aniołów wierzy w epifaniczną moc obrazu, który potrafi objawić odbiorcy podstawowe prawdy na temat rzeczywistości - tak jak widok strumienia przynosi patrzącemu rozpoznania na temat natury czasu oraz płynności świata. Kino pozwala na kontakt $\mathrm{z}$ archetypowymi obrazami, jednak elementy rzeczywiste zostają w filmie umieszczone w innych układach czasoprzestrzennych. Co najważniejsze, zdaniem Wójcika odbiorca nie powinien jedynie biernie śledzić przestrzeni reprezentacji. Kluczowe jest uczestnictwo, wchłonięcie obrazów i spotkanie z dziełem artystycznym, poszerzające granice poznania, wrażliwości i świadomości podmiotu. Właśnie taką formę kontaktu z obrazami Wójcik nazywa gnoza optyczną (s. 77-79). Elementem mającym wyjątkowe znaczenie jest w koncepcji polskiego operatora oczywiście światło traktowane jako elementarny składnik obrazu filmowego, a jednocześnie energia, która pozwala zaistnieć wszelkiej materii i wskazuje na to, co niewidzialne (s. 147-149). Trzeba dodać, że przedstawiając osobiste rozważania o świetle, Wójcik nie ogranicza się do „gnostyckich” stwierdzeń, ale odwołuje się do wiedzy operatorskiej, filozoficznej, a nawet fizycznej.

Koncepcja Jerzego Wójcika znacząco odbiega od współczesnej teorii kina, dlatego łatwo oskarżyć ją o anachronizm. Obecność jednego sensu w utworze filmowym została już dawno zakwestionowana przez postmodernizm, pojęcie ,dzieła sztuki” jest coraz częściej odrzucane przez badaczy, a od filmów przeważnie nie oczekuje się już, by były wirtuozerskie formalnie, „głębokie” i doskonale skomponowane. Słowa autora, który na wstępie zapowiada, że powinniśmy umieć rozróżnić i obronić to, co jest najważniejsze, to, co jest prawe (s. 13), mogą się wydawać głosem z innej epoki. Niektóre tezy i przekonania Wójcika mogą skłaniać odbiorcę kultury współczesnej do sprzeciwu, dyskusji i polemik. Bogatych idei artysty nie należy jednak sprowadzać do pochwały dawnego modelu sztuki - wiele jego spostrzeżeń ma w istocie nowoczesny charakter. Po pierwsze autor podkreśla ogromną rolę widza i traktuje film jako przestrzeń spotkania. Po drugie uznaje kino 


\section{O JĘZYKU KINA INACZEJ}

za medium myśli, co w nieoczekiwany sposób zbliża go do teoretyków reprezentujących zupełnie odmienne podejście badawcze, takich jak Gilles Deleuze czy Thomas Elsaesser. Jak pisze Wójcik, wszystkie elementy języka filmu stużą do tego, żeby zwizualizować ruch myśli. Jego wyrażenie jest możliwe. To jest ruch najbardziej subtelny. Pojęcie dotyczace ruchu myśli znajduje się niejako u podstaw każdego wyrażenia filmowego (s. 43).

Jednocześnie autor pokazuje, jak ów „,ruch myśli” może zostać wyrażony za pomocą misternej i wieloznacznej formy audiowizualnej. Dzieje się tak chociażby w Matce Joannie od Aniołów, w której Wójcik opowiedział o skomplikowanej relacji między dobrem a złem za pomocą bieli, czerni i szarości. Barwy nie mają tu znaczenia alegorycznego, ale w autonomiczny, czysto wizualny sposób oddają konflikt głównego bohatera. Nie trzeba bowiem dodawać, że zdaniem autora w centrum struktury filmowej zawsze jest umieszczony człowiek wraz z jego problemami egzystencjalnymi. Wydaje się, że pełna filozoficznych stwierdzeń Sztuka filmowa byłaby książką jeszcze bardziej interesującą, gdyby Wójcik podawał więcej podobnych przykładów filmowych. Ograniczenie to wynikło jednak z konieczności, ponieważ w publikacji nie można było zawrzeć analiz dokonywanych przez autora na bieżąco podczas projekcji filmów wyświetlanych po wykładach.

Sztuka filmowa nie jest książką akademicką. Autor przedstawia własny punkt widzenia na kino, a formułowane przez niego tezy nie zawsze można zweryfikować naukowo. Kojarzy zjawiska z wielu różnych dziedzin i płynnie przechodzi od opisu konstrukcji źdźbła zboża do charakterystyki kompozycji filmowej, od fizyki kwantowej do koncepcji światła w ikonach, od przedstawienia swojego snu do interpretacji Stalkera. Powołuje się przy tym na prawosławnych myślicieli (Siergieja Bułgakowa), fenomenologów (Edmunda Husserla, Romana Ingardena) oraz fizyków (Davida Bohma). To łączenie dyscyplin i przekraczanie granic okazuje się inspirujące. Książka Wójcika może rozczarować czytelników szukających praktycznej wiedzy o języku filmowym, ale niewątpliwie rozszerza horyzonty filmoznawstwa i kieruje uwagę na obszary współcześnie zaniedbywane. Poza tym, nawet odbiorcy, których zupełnie nie przekonuje filozoficzno-mistyczna, osobista wizja kina autora, znajdą tu coś dla siebie. Niezależnie od tego, czy czytelnik wierzy w duchową moc oddziaływania arcydzieł, czy nie, Sztuka filmowa przypomina bowiem o wielkim bogactwie kina jako medium opowiadania o człowieku - bogactwie, które tak rzadko jest w pełni wykorzystywane.

ROBERT BIRKHOLC

Jerzy Wójcik, Sztuka filmowa, oprac. Seweryn Kuśmierczyk, CANONIA, Warszawa 2017.

${ }^{1}$ J. Wójcik, Labirynt światła, oprac. S. Kuśmierczyk, Warszawa 2006.

${ }^{2}$ Zob. J. Żórawski, O budowie formy architektonicznej, Warszawa 1962.

${ }^{3}$ Zob. S. Kuśmierczyk, Wyprawa bohatera $w$ filmie Popiół i diament, w: tegoż, Wyprawa bohatera $w$ polskim filmie fabularnym, Warszawa 2014, s. 47-100.

${ }^{4}$ Zob. S. Kuśmierczyk, Między świattem nieba a szarościa piasku. Sztuka operatorska w Fa- raonie, w: Faraon. Poetyka filmu, red. S. Kuśmierczyk, Warszawa 2016, s. 263.

${ }^{5} \mathrm{O}$ inspiracji sztuką ikon w Stalkerze Andrieja Tarkowskiego pisał wcześniej Seweryn Kuśmierczyk, do którego odwołuje się Wójcik. Zob. S. Kuśmierczyk, ,Stalker” jako ikona, „Kwartalnik Filmowy” 1995, nr 9-10. 